\title{
Możliwości zachowania resztek słuchowych i struktury ucha wewnętrznego po wszczepieniu implantu ślimakowego u pacjentów z zespołem Ushera
}

\section{Methods of preserving the residual hearing and inner ear structures during implantation in patients with the Usher syndrome}

\author{
Piotr Henryk Skarżyński ${ }^{1,2,3}$, Ewa Tomanek ${ }^{1,2}$, Bartłomiej Król ${ }^{1}$, Adam Piłka ${ }^{1}$ \\ ${ }^{1}$ Instytut Fizjologii i Patologii Słuchu, Warszawa/Kajetany \\ ${ }^{2}$ Warszawski Uniwersytet Medyczny, Zakład Diagnostyki i Rehabilitacji Okulistycznej i Narządów Zmysłu, \\ Warszawa \\ ${ }^{3}$ Instytut Narządów Zmysłów, Warszawa
}

Adres autora: Piotr H. Skarżyński, Zakład Diagnostyki i Rehabilitacji Okulistycznej i Narządów Zmysłu, ul. Sierakowskiego 13, 03-709 Warszawa, e-mail: p.skarzynski@wum.edu.pl

\section{Streszczenie}

Wstęp: Zespół Ushera to choroba rzadka, występująca w zależności od populacji na poziomie od 3,5 do 6,2 na 10000 osób. Jej najbardziej charakterystyczne objawy to: różnego rodzaju głuchota lub częściowa głuchota, zaburzenia układu równowagi i ślepota pojawiająca się w różnym wieku.

Cel: Celem niniejszej pracy było przeanalizowanie zachowania resztek słuchowych wśród pacjentów z zespołem Ushera podanych procedurze leczenia częściowej głuchoty (Partial Deafness Treatment).

Metoda: Operacje wszczepienia implantu ślimakowego zostały przeprowadzone według metody 6 kroków Skarżyńskiego. Insercji elektrody dokonano przez okienko okrągłe, ale w niektórych przypadkach zastosowano, ze względów anatomicznych, dojście przez kochleostomię. Ocena zachowania resztek słuchowych była dokonywana na podstawie wyników audiometrii tonalnej wykonanej przed zabiegiem i po nim.

Wyniki: Analiza wyników audiometrii tonalnej, wykonanej w tych samych warunkach przed zabiegiem operacyjnym i po nim, wykazała zachowanie resztek słuchowych po wszczepieniu elektrody do ślimaka.

Wnioski: Zespół Ushera charakteryzuje się, w większości przypadków, progresywnym niedosłuchem. Dlatego podczas dalszej obserwacji pacjentów może się okazać, że będzie potrzebna zmiana sposobu kodowania dźwięku w zależności od kanału elektrody. Rekomendowana jest głębsza insercja elektrody - od $25 \mathrm{~mm}$ do $28 \mathrm{~mm}$, w zależności od wielkości ślimaka.

Słowa kluczowe: zespół Ushera • częściowa głuchota • Partial Deafness Treatment • okienko okrągłe • implant ślimakowy

Abstract

Background: Usher Syndrome is a rare disease with prevalence, vary depending on population, on level 3.5 to 6.2 on 10,000 people. The most characteristic features of the disease are: different types of deafness and partial deafness, vestibular disorders and blindness which occurs sooner or later.

Aim of the study: The main aim of that study is to evaluate possible hearing deterioration after cochlear implantation.

Method: Cochlear implantation surgery was performed according to 6 steps surgery. In majority of cases electrode insertion was performed by the round window and in some cases through cochleostomy. It was due to anatomic condition. 
Results: After analysis of pure tonal audiometry, performed under the same condition, there was very good hearing preservation in almost all cases.

Conclusions: In majority of cases Usher syndrome is characterized by progressive hearing loss. It is important from pre surgical assessment how deep should be insertion of electrode. It is recommended to look after such patients more often. Insertion from 25 to $28 \mathrm{~mm}$ is recommended.

Key words: Usher syndrome • partial deafness $\bullet$ Partial Deafness Treatment $\bullet$ round window approach $\bullet$ cochlear implant

\section{Wstęp}

Zespół Ushera jest to uwarunkowana genetycznie (sposób dziedziczenia autosomalny recesywny) jednostka chorobowa, charakteryzująca się postępującym obustronnym niedosłuchem odbiorczym oraz progresywną utratą wzroku, wtórną do zwyrodnienia barwnikowego siatkówki. Jest to choroba rzadka, ale jednocześnie stanowi najczęstszą przyczynę równoczesnej dysfunkcji dwóch najważniejszych dla prawidłowego rozwoju człowieka zmysłów, jakimi są słuch i wzrok [1-3].

Specyficzne dla zespołu objawy opisał w 1858 r. niemiecki okulista Albrecht von Graefe. Zaobserwował on, że bardzo podobne symptomy występują u trojga spośród pięciorga leczonego przez niego rodzeństwa. Pomimo że von Graefe jako pierwszy zwrócił uwagę na współwystępowanie objawów oraz prawdopodobieństwo genetycznego podłoża choroby, obecna i powszechnie przyjęta nazwa zespołu pochodzi od nazwiska Charlesa Ushera, szkockiego lekarza, który w 1914 r. przez opisanie 41 rodzin określił sposób dziedziczenia choroby i publicznie zaprezentował swoje odkrycie [4]. W literaturze możemy spotkać również inne określenia zespołu Ushera, takie jak: Hallgren syndrome, Usher-Hallgren syndrome, retinitis pigmentosa (RP)-dysacusis syndrome i dystrophia retinae dysacusis syndrome [2].

Zespół Ushera jest bardzo heterogeniczny zarówno $\mathrm{w}$ aspekcie objawów klinicznych, jak i podłoża genetycznego. Istnieje kilka klasyfikacji choroby. Dotychczas scharakteryzowano trzy typy zespołu Ushera: 1, 2 i 3. Podstawami ich rozróżnienia są: stopień i progresja niedosłuchu, obecność lub brak zaburzeń równowagi oraz wiek pacjenta, w którym pojawia się nieprawidłowość widzenia [5].

Zespół Ushera typu 1 (USH1) ma najcięższy przebieg i jest najczęstszy, według danych literaturowych stanowi aż 30-40\% przypadków w ogólnej populacji chorych z zespołem Ushera [2]. USH1 cechuje głęboki niedosłuch prelingwalny, w którym - jak podaje literatura - resztki słuchowe w zakresie niskich częstotliwości mogą mieścić się $\mathrm{w}$ granicach od $90 \mathrm{~dB}$ do $100 \mathrm{~dB}$ [2]. Ponadto w typie 1 występuje zaburzenie funkcji przedsionka, skutkujące zaburzeniami równowagi i opóźnionym rozwojem motorycznym dziecka, oraz postępujące peryferyczne niedowidzenie, które pojawia się już w pierwszej dekadzie życia, prowadząc do całkowitej utraty wzroku [6]. Zespół Ushera typu 2 (USH2) objawia się początkowo niewielkim, ale często progresywnym ubytkiem słuchu, prawidłowo zachowanym narządem równowagi i analogiczną, ale rozpoczynającą się dopiero w drugiej dekadzie życia utratą wzroku. Niedosłuch dotyczy prawie wszystkich chorych. W niektórych przypadkach progresja niedosłuchu może nie pojawić się [10]. Zespół Ushera typu 3 (USH3) statystycznie występuje najrzadziej. Jego symptomy ujawniają się stosunkowo najpóźniej w porównaniu z poprzednimi dwoma typami. Chory po urodzeniu słyszy, problemy zaczynają stopniowo narastać od drugiej dekady życia, zaburzenia równowagi nie zawsze są obecne, a wady wzroku ujawniają się około drugiej, trzeciej dekady życia [10].

Dotychczas scharakteryzowano 12 loci i 9 genów, których zmiany odpowiedzialne są za wystąpienie choroby. Za występowanie USH1 odpowiadają mutacje zlokalizowane w pięciu genach kodujących białka: miozynę VIIA, PDS-95, harmoninę, kadhedrynę-23 i protokadhedrynę-15. USH2 powstaje na skutek mutacji genów kodujących białka: przezbłonowe białko - uszerynę, białka VLGR1 (very large G-protein-coupled receptor-1) i wirlinę. Według danych literaturowych za wystapienie USH3 odpowiedzialna jest mutacja tylko jednego genu: klaryny-1 [7]. Kodowane przez te geny białka odpowiadają m.in. za prawidłową funkcję komórek włoskowatych ucha wewnętrznego, a tym samym prawidłową percepcję słuchową.

Zespół Ushera stwierdza się u około 50\% przypadków pacjentów $\mathrm{z}$ równocześnie występującym uszkodzeniem słuchu i wzroku [5-7]. Szacuje się, że choroba dotyczy od 3\% do $6 \%$ pacjentów $\mathrm{z}$ wrodzona głuchotą oraz od $8 \%$ do $33 \%$ osób ze zdiagnozowanym zwyrodnieniem barwnikowym siatkówki [5,6]. Rozpowszechnienie zespołu w różnych populacjach ocenia się na 3,5-6,2 na 100000 osób [5]. Występowanie choroby jest bardziej powszechne w populacjach izolowanych, w których związki małżeńskie są zawierane między bliskimi krewnymi, np. wśród Żydów aszkenazyjskich, Huterianów [5]. Według niektórych danych częstość jej występowania waha się od 1:12 500 w Niemczech do 1:23 000 w Stanach Zjednoczonych [8].

\section{Cel}

Celem pracy jest ocena rezultatów i korzyści, jakie płyną z zastosowania implantacji ślimakowej w procedurze Partial Deafness Treatment (PDT) w grupie pacjentów, których postępujący niedosłuch ma podłoże genetyczne [9]. Przedmiotem badań była analiza choroby rzadkiej, jaką jest zespół Ushera.

\section{Materiał i metody}

Materiał stanowiło 10 przypadków wyselekcjonowanych spośród 3781 pacjentów poddanych implantacji ślimakowej w Instytucie Fizjologii i Patologii Słuchu (Światowe Centrum Słuchu) w latach 1999-2012 (tabela 1). Badaniami objęto: 5 mężczyzn i 5 kobiet, w wieku od 24 do 62 lat. Wszyscy badani wykazywali kliniczne objawy zespołu Ushera: obustronne odbiorcze uszkodzenie słuchu, zaburzenia widzenia oraz w kilku przypadkach zaburzenia równowagi. 
Tabela 1. Zestawienie pacjentów z zespołem Ushera, którym został wszczepiony implant ślimakowy w ramach procedury leczenia częściowej głuchoty (PDT)

Table 1. Summary of patients with Usher syndrome, which have been implanted cochlear implant using the Partial Deafness Treatment (PDT)

\begin{tabular}{cccccc}
\hline $\begin{array}{c}\text { Wiek rozpoczęcia } \\
\text { użytkowania aparatu } \\
\text { słuchowego (strona) }\end{array}$ & $\begin{array}{c}\text { Wiek } \\
\text { wszczepienia } \\
\text { implantu } \\
\text { slimakowego }\end{array}$ & $\begin{array}{c}\text { Strona } \\
\text { implantacji }\end{array}$ & Dojście chirurgiczne & Rodzaj implantu & $\begin{array}{c}\text { Rozwiązanie } \\
\text { stosowane } \\
\text { po operacji }\end{array}$ \\
\hline 9 (P) & 36 & prawa & okienko okrągłe & Medel Pulsar Cl100 & $\mathrm{Cl}, \mathrm{HA}$ \\
\hline $7(\mathrm{O})$ & 36 & prawa & okienko okrągłe & Medel Sonata Tl100 & $\mathrm{Cl}, \mathrm{HA}$ \\
\hline $7(\mathrm{O})$ & 33 & prawa & okienko okrągłe & Medel C40+ & $\mathrm{Cl}, \mathrm{HA}$ \\
\hline $13(0)$ & 34 & prawa & kochleostomia & Medel C40+ & tylko Cl \\
\hline $50(0)$ & 55 & prawa & kochleostomia & Advanced Bionics & tylko Cl \\
\hline $45(\mathrm{~L})$ & 52 & prawa & kochleostomia & Cochlear Cl 24R (ST) & tylko Cl \\
\hline Dzieciństwo (O) & 52 & lewa & okienko okrągłe & Medel Plusar Cl 70 & $\mathrm{Cl}, \mathrm{HA}$ \\
\hline Dzieciństwo (O) & 28 & lewa & okienko okrągłe & Medel Pulsar Cl100 & tylko Cl \\
\hline $9(P) 13(0)$ & 24 & lewa & okienko okrągłe & Medel Pulsar Cl100 & $\mathrm{Cl}, \mathrm{HA}$ \\
\hline $1(\mathrm{O})$ & 18 & lewa & kochleostomia & Cochlear Cl 24RE & $\mathrm{Cl}, \mathrm{HA}$ \\
\hline
\end{tabular}

$\mathrm{P}$ - prawa, L - lewa, O - obustronnie, Cl - implant ślimakowy, HA - aparat słuchowy

W ramach procedury diagnostycznej u pacjentów przeprowadzono badania audiologiczne, a u niektórych osób także badania genetyczne, w celu wybrania optymalnej metody leczenia. Analiza przypadków opierała się na historiach chorób pacjentów, pooperacyjnych wizytach kontrolnych. W zakresie zachowania słuchu analizowano pomiary audiometryczne wykonane w Światowym Centrum Słuchu przez tych samych specjalistów przed operacją, 1 miesiąc po operacji, 6 miesięcy oraz w okresie 12-18 miesięcy po operacji.

Wszyscy pacjenci niezależnie od wieku, w którym zostali poddani operacji wszczepienia implantu, przed zabiegiem korzystali z aparatów słuchowych. We wszystkich przypadkach aparat słuchowy nie dawał wystarczających korzyści. W 9 przypadkach niedosłuch o różnym stopniu nasilenia został zdiagnozowany poniżej 14 rż., w tym u dwojga pacjentów w okresie niemowlęctwa. Zgodnie z historią choroby tylko u jednego $\mathrm{z}$ chorych niedosłuch pojawił się powyżej drugiej dekady życia, w wieku 45 lat.

W pracy skoncentrowano się na aspektach otologicznych choroby, jednak w celu diagnostyki zespołu Ushera niezbędne było określenie sprawności narządu wzroku. Okazało się, że u dziewięciorga pacjentów zaburzenia widzenia pojawiły się przed 23 rż. Istotne było również określenie sposobu komunikacji pacjentów z otoczeniem. Wśród uczestników badania dziewięcioro rozwinęło mowę (głuchota postlingwalna), natomiast jeden z pacjentów komunikuje się za pomocą języka migowego (głuchota prelingwalna).

Na skutek postępującego niedosłuchu, a w konsekwencji braku efektywności aparatów słuchowych, pacjenci zostali skierowani do wszczepienia implantu ślimakowego. Wyniki badań audiometrycznych wszystkich badanych ujawniły głęboki niedosłuch. Wśród chorych $\mathrm{z}$ zespołem Ushera najmłodszy pacjent, który został poddany operacji, miał 18 lat, natomiast najstarszy 55 lat. Wybór operowanego ucha (w 4 przypadkach lewego, w 6 prawego) zależał od wyników badań audiometrycznych oraz subiektywnej oceny pacjenta. Preferowaną metodą dostępu do ślimaka było operacyjne dojście przez okienko okrągłe [9]. W 4 przypadkach ze względów anatomicznych elektrodę wprowadzono przez kochleostomię. Zastosowano implanty ślimakowe trzech producentów (Advanced Bionics, Cochlear i Medel). Wszystkie operacje przebiegły bez powikłań. Po operacji 4 pacjentów korzysta tylko $\mathrm{z}$ implantu ślimakowego, natomiast $6 \mathrm{z}$ implantu oraz aparatu słuchowego po stronie przeciwnej.

\section{Wyniki}

Badaniem, które było analizowane w tej pracy, była audiometria tonalna. Wykonana została na częstotliwościach oktawowych: $125 \mathrm{~Hz}, 250 \mathrm{~Hz}, 500 \mathrm{~Hz}, 1000 \mathrm{~Hz}, 2000 \mathrm{~Hz}$, $4000 \mathrm{~Hz}$. Nie brano pod uwagę częstotliwości $8000 \mathrm{~Hz}$. Analizowano ucho implantowane oraz ucho nieimplantowane. Na wszystkich częstotliwościach w obserwacji do 6 miesiąca po operacji wszczepienia implantu ślimakowego nie zaobserwowano pogorszenia słuchu powyżej $10 \mathrm{~dB}$. W obserwacji ponad rocznej pogorszenie słuchu nie było większe niż $20 \mathrm{~dB}$ (rycina 1). Pomimo braku implantacji w uchu kontrlateralnym, wyniki audiometrii tonalnej były porównywalne i w dłuższym (ponad rok od operacji) okresie obserwacji (rycina 2).

\section{Dyskusja}

Cechą charakterystyczną zespołu Ushera jest nieunikniona utrata słuchu oraz postępujące niedowidzenie. W literaturze na wybranych grupach pacjentów analizuje się szybkość progresji utraty słuchu w zależności od typu zespołu. Jedno $\mathrm{z}$ badań przeprowadzonych na 125 pacjentach z obserwacją 17-letnią pokazuje, że w zespole Ushera 

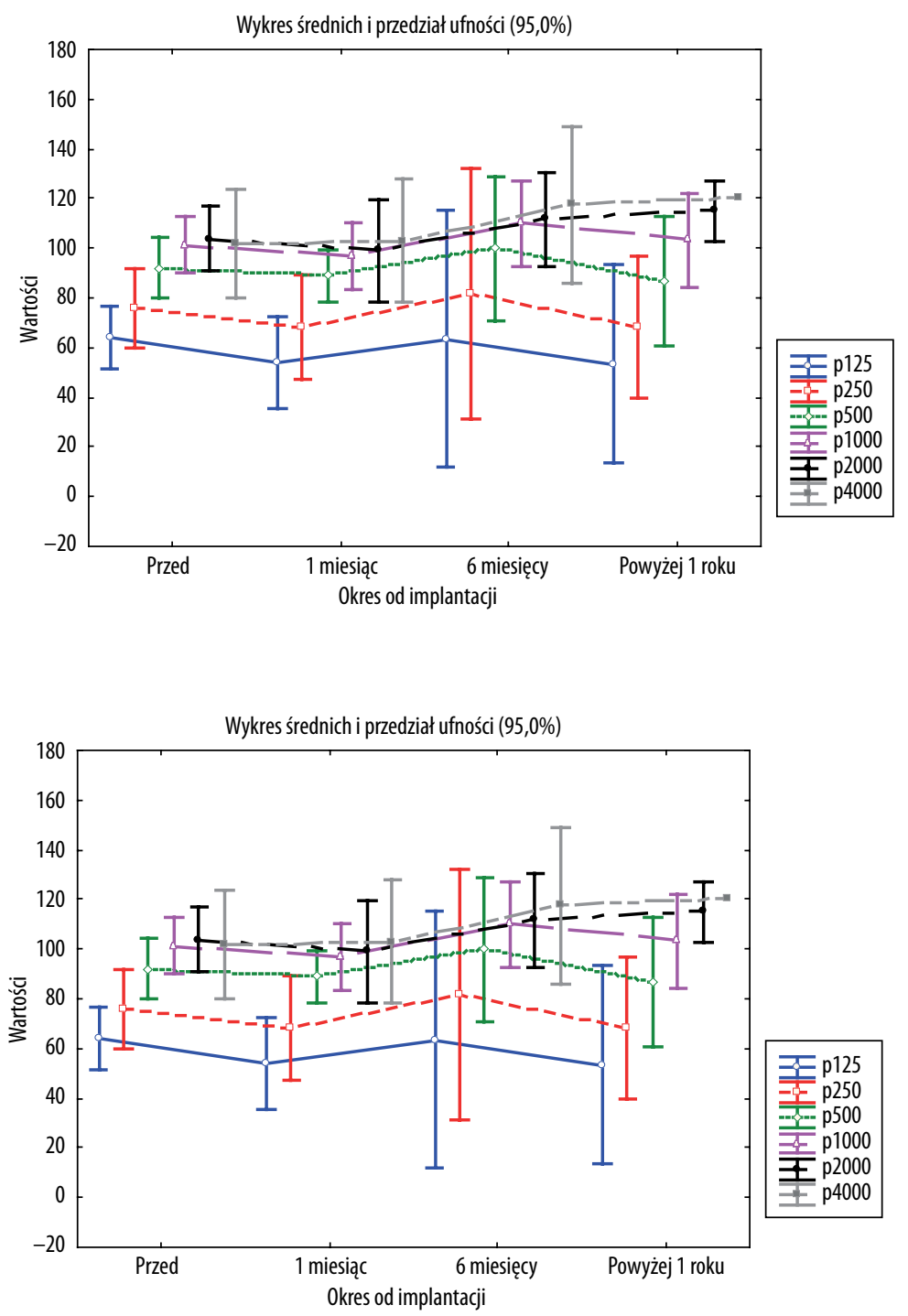

Rycina 1. Wyniki badania audiometrii tonalnej przed implantacją i po implantacji na poszczególnych częstotliwościach (od $125 \mathrm{~Hz}$ do $4000 \mathrm{~Hz}$ ) podane $w$ decybelach $[\mathrm{dB}]-$ ucho implantowane

Figure 1. Audiometric test results before and after implantation at different frequencies (from $125 \mathrm{~Hz}$ to $4000 \mathrm{~Hz}$ ) shown in decibels $[\mathrm{dB}]$ - implanted ear

Rycina 2. Wyniki badania audiometrii tonalnej przed implantacją i po implantacji na poszczególnych częstotliwościach (od $125 \mathrm{~Hz}$ do $4000 \mathrm{~Hz}$ ) podane $w$ decybelach $[\mathrm{dB}]-\mathrm{ucho}$ nieimplantowane

Figure 2. Audiometric test results before and after implantation at different frequencies (from $125 \mathrm{~Hz}$ to $4000 \mathrm{~Hz}$ ) shown in decibels $[\mathrm{dB}]$ - non-implanted ear typu 2 progresja w zasadzie nie występuje [11]. W chwili obecnej nie jest znany sposób zapobiegania tego typu zmianom, nie ma również skutecznej metody ani przyczynowego, ani objawowego leczenia choroby. Aktualnie jedyną dostępną formą pomocy pacjentom jest efektywne protezowanie narządu słuchu. Wyniki pacjentów z zespołem Ushera, którym wszczepiono implant ślimakowy, są porównywalne $\mathrm{z}$ wynikami innych pacjentów $\mathrm{z}$ resztkami słuchowymi (z inną niż zespół Ushera etiologią częściowej głuchoty) korzystającymi z tego urządzenia [9]. Dzięki implantacji ślimakowej chorzy mają większe szanse na niezależne życie oraz możliwość komunikacji z otoczeniem. Badania prowadzone w różnych krajach na różnych populacjach pokazują, że rozwiązanie to jest efektywne. Ze względu na postępującą ślepotę sugeruje się, aby pacjentów implantować dosyć wcześnie (jeśli choroba jest rozpoznana) [12]. Ze względu na zmiany w centralnym układzie nerwowym zalecana jest implantacja obustronna sekwencyjna [2-4,12]. Pomimo preferowanej w Partial Deafness Treatment metody chirurgicznej polegającej na uzyskaniu dostępu do ślimaka przez okienko okrągłe [9] u części pacjentów zastosowano kochleostomię.

\section{Wnioski}

Poddani analizie pacjenci wymagają podejścia interdyscyplinarnego. Wyniki badań pacjentów po operacji wszczepienia implantów ślimakowych są bardzo dobre. Średnia zmiana jest niższa niż $8 \mathrm{~dB}$ (wg danych: do 1 roku po przeprowadzonej operacji). Otrzymane rezultaty analizy dowodzą, że z klinicznego punku widzenia Partial Deafness Treatment jest procedurą bezpieczną i efektywną. W praktyce występują problemy z regularnością zgłaszania się pacjentów na wizyty kontrolne. U niektórych pacjentów stosowane są indywidualne algorytmy programowania procesora mowy. U części z nich związane to jest $\mathrm{z}$ koniecznością opieki u innych specjalistów (najczęściej okuliści). Istotnym zagadnieniem jest stosowanie Partial Deafness Treatment nie tylko z powodu zachowania resztek słuchowych. Celem jest też zachowanie struktury ucha wewnętrznego i - jeśli to możliwe - insercja elektrody przez okienko okrągłe. Nie zawsze się to udaje u pacjentów z tym zespołem, co może stanowić istotną wskazówkę dla otochirurgów. Większość pacjentów preferuje wykorzystywanie tylko stymulacji elektrycznej. 


\section{Piśmiennictwo:}

1. Le Quesne Stabej P, Saihan Z, Rangesh N, Steele-Stallard HB, Ambrose J, Coffey A i wsp. Comprehensive sequence analysis of nine Usher syndrome genes in the UK National Collaborative Usher Study. J Med Genet, 2012; 49(1): 27-36.

2. Liu XZ, Angeli SI, Rajput K, Yan D, Hodges AV, Eshraghi A i wsp. Cochlear implantation in individuals with Usher type 1 syndrome. Int J Pediatr Otorhinolaryngol, 2008; 72(6): 841-7.

3. Jatana KR, Thomas D, Weber L, Mets MB, Silverman JB, Young NM. Usher syndrome: Characteristics and outcomes of pediatric cochlear implant recipients. Otol Neurotol, 2013; 34(3): 484-9.

4. Yan D, Liu XZ. Genetics and pathological mechanisms of Usher syndrome. J Hum Genet, 2010; 55(6): 327-35.

5. Ouyang XM, Yan D, Du LL, Hejtmancik JF, Jacobson SG, Nance WE i wsp. Ouyang Characterization of Usher syndrome type I gene mutations in an Usher syndrome patient population. Hum Genet, 2005; 116(4): 292-9.

6. Bonnet C, El-Amraoui A. Usher syndrome (sensorineural deafness and retinitis pigmentosa): pathogenesis, molecular diagnosis and therapeutic approaches. Curr Opin Neurol., 2012; 25(1): 42-9.
7. Mrugacz M. Ocena morfologii plamki oraz funkcji narządu wzroku w przebiegu zespołu Ushera. Klinika oczna, 2010; 324: $10-2$.

8. Siedlecka H. Zespół Ushera - problem nieznany. Otoscop, 1994; 1: 2-4.

9. Skarżyński H. Ten years experience with a new strategy of Partial Deafness Treatment. Journal of Hearing Science, 2012; 2(2): $11-8$.

10. Otterstedde CR, Spandau U, Blankenagel A, Kimberling WJ, Reisser C. A new clinical classification for Usher's syndrome based on a new subtype of Usher's syndrome type I. Laryngoscope, 2001; 111(1): 84-6.

11. Reisser CF, Kimberling WJ, Otterstedde CR. Hearing loss in Usher syndrome type II is nonprogressive. Ann Otol Rhinol Laryngol, 2002; 111(12 Pt 1): 1108-11.

12. Pietola L, Aarnisalo AA, Abdel-Rahman A, Västinsalo H, Isosomppi J, Löppönen $\mathrm{H}$. Speech recognition and communication outcomes with cochlear implantation in Usher syndrome type 3. Otol Neurotol, 2012; 33(1): 38-41. 